\title{
sciendo
}

\section{EFFECTS OF CAPONIZATION ON GROWTH PERFORMANCE AND MEAT PHYSICOCHEMICAL PROPERTIES OF CROSSBRED CHICKENS*}

Jolanta Calik $^{1 \star}$, Sylwester Świątkiewicz², Joanna Obrzut ${ }^{1}$, Katarzyna Połtowicz ${ }^{1}$, Józefa Krawczyk ${ }^{1}$

\author{
${ }^{1}$ Department of Poultry Breeding, \\ ${ }^{2}$ Department of Animal Nutrition and Feed Science, \\ National Research Institute of Animal Production, 32-083 Balice n. Kraków, Poland \\ •Corresponding author: jolanta.calik@izoo.krakow.pl
}

\begin{abstract}
The aim of the study was to determine the effect of caponizing on body weight and physicochemical properties of meat of the capons - hybrids obtained from the crossing of hens of the Yellowleg Partridge ( $\dot{Z}-33)$ breed with meat roosters. The study covered 80 hybrid roosters, which were randomly assigned to two groups of 40 animals each (8 boxes of 10 birds in each group). Group I (control) consisted of uncastrated roosters while group II included birds, which were castrated at 8 weeks of age under local anaesthesia by a vet. Birds were fed ad libitum with the same standard diets and kept on litter under optimal environmental conditions with a stocking density of 7 ani$\mathrm{mals} / \mathrm{m}^{2}$. At the end of fattening, i.e. in the 20 th week of life, 8 birds with a body weight close to the group average were selected from each group for slaughter. After slaughter, the effectiveness of the procedure was checked (lack of testicles), then the slaughter performance of birds, physicochemical parameters of the pectoral and leg muscles were determined, and sensory evaluation was performed. The procedure of castration of hybrid roosters had a positive effect on body weight, feed conversion ratio and carcass traits. The pectoral and leg muscles of the capons were characterized by better water absorption, tenderness and sensory evaluation compared to roosters. Among the assessed groups of birds there was also a variation in the colouring of whole carcasses and muscles, which were lighter $\left(L^{*}\right)$, more yellow $\left(b^{*}\right)$ and less red $\left(a^{*}\right)$ in caponized birds. In addition, the castration procedure had a positive effect on the total protein content in both the pectoral and leg muscles, which in turn, with a higher raw fat content, were distinguished by a favourable ratio of n-6/n-3 polyunsaturated fatty acids (PUFA). Based on the results, it can be concluded that the hybrids obtained from the crossbreeding of the Yellowleg Partridge ( $\dot{Z}-33)$ and Ross 308 meat roosters are good choice for capon production. They can complement poultry meat production with a niche product for consumers looking for products of exceptional quality.
\end{abstract}

Key words: capon, meat quality, fatty acid, sensory evaluation

\footnotetext{
*This work was funded by project no. 03-17-11-09.
} 
Currently, there is an increase in the number of consumers looking for products from native breed or hybrid slaughter chickens reared in semi-intensive or extensive conditions, with the high sensory qualities (Augustyńska-Prejsnar and Sokołowicz, 2014; da Silva et al., 2017). The authors emphasize that as a result of the continuous shortening of the rearing period, the meat of broiler chickens is less mature and has worse technological parameters compared to slow-growing chickens, especially chickens of native breeds. In Poland, we have a valuable collection of laying hen breeds covered by the genetic resource conservation program, most of which have been entered by the FAO in the World Watch List. These families and their hybrids are phenotypically and productively diverse, and perfectly fit into organic production, providing products with good taste and dietary qualities (Połtowicz and Doktor, 2012; Puchała et al., 2014; Krawczyk and Calik, 2018). Unfortunately, it is very difficult to link the laying hens with their use for meat production, due to the number of unnecessary cockerels (around 50\%). The solution to these difficulties may be the caponizing procedure, especially with the returning trend for dishes from the old Polish cuisine in recent years, in which the capon (Calik, 2014) or the poularde a young sterilized hen (Obrzut et al., 2018) were the basis for making exquisite dishes.

A capon is a male hen, surgically castrated before reaching sexual maturity and slaughtered at the age of at least 140 days (20 weeks), and after the procedure, the capons must be fattened for a minimum of 77 days (Regulation EC No. 543/2008 of 16 June 2008). Nowadays, a larger scale bird sterilization procedure is performed in China, Taiwan and the USA, and in Europe: in France, Spain and Italy, where capons are marketed as products of high, special quality (Sirri et al., 2009; Amorim et al., 2016). The most frequently used native breeds are e.g. Bresse in France, Castellana Negra in Spain, Hinai-Jidori in Japan, Jersey Giant, Brahms, Plymouth Rocks and Cochin in the USA (Symeon et al., 2010; 2012), and hen breeds in Poland: Greenleg Partridge, Yellowleg Partridge or Rhode Island Red (Calik, 2014).

Comparison of slaughter performance and meat quality of cockerels and capons by origin, age, breeding system and nutrition has been the subject of many studies (Tor et al., 2002; Rahman et al., 2004; Tor et al., 2005; Sirri et al., 2009; Symeon et al., 2010; Rikimaru et al., 2011; Sinanoglou et al., 2011; Volk et al., 2011; Symeon et al., 2012; Mahmud et al., 2013; Calik et al., 2015; Kwiecień et al., 2015; Adamski et al., 2016 a, b; Amorim et al., 2016; Calik et al., 2017; Zawacka et al., 2017; 2018; Kwiecień et al., 2018; Murawska et al., 2019; Wojtysiak et al., 2019). The results of these studies unequivocally prove that as a result of the capon's surgery, the accumulation of fat tissue in the abdominal cavity, subcutaneous fat, and especially intramuscular fat increases, which makes the capon meat characterized by greater fineness, juiciness and tenderness. The authors also emphasize that a higher content of fat tissue in capons has a positive effect on improving the taste characteristics. This is important for consumers, who are increasingly looking for products with better palatability. Our own research shows that the results of capon rearing and fattening obtained from pure hen families required a longer rearing period due to slow weight gain (Calik, 2015; Calik et al., 2015, 2017). Thus, an attempt was made to have capon production using hybrids obtained from the crossing of meat roosters 
with hens of the Yellowleg Partridge ( $\dot{Z}-33)$ breed, which is distinguished from other native breeds by its good quality and favourable sensory qualities of meat (Puchała et al., 2014; Obrzut et al., 2018).

The aim of the study was to determine the effect of the caponizing procedure on the body weight and physicochemical properties of the meat of hybrid capons obtained from the crossing of hens of the Yellowleg Partridge ( $\dot{\mathrm{Z}}-33)$ breed with meat roosters.

\section{Material and methods}

The experimental material consisted of hybrids obtained from the crossing of hens of the Yellowleg Partridge ( $\dot{Z}-33)$ breed and meat roosters Ross 308. The birds, after being weighed and individually marked, were randomly assigned to two groups of 40 birds each ( 8 boxes of 10 birds in each group). Group I (control group) consisted of uncastrated cockerels; birds from group II, i.e. experimental ones, were castrated under local anaesthesia in the 8th week of life. The experimental procedures complied with the requirements established by the Ethics Commission No. 1121 of 27 November 2014.

Table 1. Composition and nutrient content of the diets used in the experiment $(\mathrm{kg} / 100 \mathrm{~kg})$

\begin{tabular}{|c|c|c|c|}
\hline \multirow{2}{*}{ Component } & Phase I & Phase II & Phase III \\
\hline & day 1 to week 7 & weeks 8 to 16 & weeks 17 to 20 \\
\hline Ground maize & 41.35 & 40.45 & 36.00 \\
\hline Ground wheat & 25.00 & 22.00 & 29.40 \\
\hline Ground triticale & - & 5.00 & 6.00 \\
\hline Ground barley & - & 5.00 & 6.00 \\
\hline Soybean meal & 30.00 & 24.00 & 15.50 \\
\hline \multicolumn{4}{|l|}{ Milk powder } \\
\hline ( $32.7 \%$ protein, $3.0 \%$ fat) & - & - & 4.00 \\
\hline Ground limestone & 1.25 & 1.30 & 1.15 \\
\hline Dicalcium phosphate & 1.60 & 1.45 & 1.15 \\
\hline $\mathrm{NaCl}$ & 0.30 & 0.30 & 0.30 \\
\hline $\begin{array}{l}\text { Vitamin-mineral premix DKA-F (finisher) } \\
(0.5 \%), \mathrm{kg}\end{array}$ & 0.50 & 0.50 & 0.50 \\
\hline Crude protein $(\mathrm{g})$ & 204 & 184 & 165 \\
\hline Metabolizable energy (MJ) & 11.92 & 12.05 & 12.18 \\
\hline (kcal) & 2850 & 2880 & 2910 \\
\hline Lys (g) & 10.3 & 8.90 & 7.50 \\
\hline Met (g) & 3.10 & 2.85 & 2.60 \\
\hline $\mathrm{Ca}(\mathrm{g})$ & 8.95 & 8.60 & 7.90 \\
\hline $\mathrm{P}$ available $(\mathrm{g})$ & 4.10 & 3.80 & 3.50 \\
\hline
\end{tabular}


The birds were kept in standard environmental conditions (temperature $16-18^{\circ} \mathrm{C}$ and relative air humidity about $60-75 \%$ ) in the floor raising system with a stocking density of 7 birds $/ \mathrm{m}^{2}$. During the entire period of rearing and fattening, i.e., until the 20th week of age, the roosters and capons were fed ad libitum with complete mixtures developed in the National Research Institute of Animal Production: starter, grower and finisher diets with $4 \%$ addition of milk powder. The component composition and the results of the chemical analysis of feed materials according to the AOAC (2000) methodology are shown in Table 1.

In the 20th week of life, birds from each group were selected for slaughter, 8 birds of near average body weight in each group. Roosters and capons did not receive feed for about 12 hours before slaughter, but had constant access to water. After slaughter in group II, the effectiveness of the procedure was checked (lack of testicles), followed by standard post-slaughter treatment (scalding, plucking, gutting). Then, using the Minolta CR 310 (Konica Minolta Holdings, Inc., Japan), the colour of the skinned whole poultry was determined (colour results are the average of 5 whole poultry measurements). Chilled whole poultry $\left(24 \mathrm{~h}\right.$ at $\left.4^{\circ} \mathrm{C}\right)$ were subjected to simplified slaughter analysis according to Ziołecki's and Doruchowski's (1989) methodology. The following were determined: slaughter yield with offals, slaughter yield without offals, proportion of: pectoral and leg muscles, offals (liver, gizzard, heart), leg bones and abdominal fat.

Samples of the pectoral and leg muscles were taken from each whole poultry, and the physicochemical characteristics of the meat were assessed. Acidity was determined 15 minutes $\left(\mathrm{pH}_{15}\right)$ and 24 hours $\left(\mathrm{pH}_{24}\right.$ - ultimate $\left.\mathrm{pH}\right)$ postmortem using a CyberScan $110 \mathrm{pH}$ meter equipped with a glass electrode for meat analysis (Eutech Instruments Pte Ltd/Oakton Instruments with Hamilton glass electrode, calibration at $\mathrm{pH} 4.0$ and 7.0). Colour was determined $24 \mathrm{~h}$ postmortem with the L*a*b* system (CIE, 2007), using a Minolta CR 310 reflectance colorimeter (Konica Minolta Holdings, Inc., Japan; light source D65, observer $2^{\circ}$ ), where $\mathrm{L}^{*}$ means brightness, a positive $a^{*}$ value means redness, and a positive $b^{*}$ value means yellowness. The colour result is the mean of five whole bird measurements ( 1 measurement from the dorsal part, 2 measurements from the thoracic part, 2 measurements from the thigh part of the legs), while the muscle colour is the mean of 2 measurements of the breast muscle and 2 femoral muscle measurements taken on the inner surface immediately after bone separation. Water-holding capacity (WHC) was determined based on the volume of juices squeezed from a sample; WHC of breast muscles and leg muscles (thigh) was determined using the Grau and Hamm method (1953) based on the amount of juice mechanically pressed from the sample onto a filter paper (Whatman, 1 Qualitative, Cat No 1001 917, UK Limited); and the leakage area was estimated using a planimeter (Haff Digital Polar Planimeter No. 301, Germany). Drip and cook loss determination - the meat juice leakage - was determined after storing the samples of breast muscles and thigh muscles for 24 hours at $+4^{\circ} \mathrm{C}$. In order to do this, $80 \mathrm{~g}$ meat samples were collected from the thigh and the pectoral muscle which were then placed in tightly sealed containers and stored in a refrigerator. Next, the samples were weighed and the leak was calculated according to the formula: 


$$
\text { drip loss }(\%)=\frac{\begin{array}{c}
\text { sample weight before refrigeration }(g)-\text { sample weight after } \\
\text { refrigeration }(g)
\end{array}}{\text { sample weight before refrigeration }(g)} \times 100
$$

Thermal loss was determined as the loss in weight of breast and thigh muscles during cooking. Eighty g samples were placed in plastic bags and cooked at $100^{\circ} \mathrm{C}$ for $14 \mathrm{~min}$ (breast muscles) and $16 \mathrm{~min}$ (thigh muscles) to an internal temperature of $76-78^{\circ} \mathrm{C}$. After cooking, the samples were chilled at room temperature for $30 \mathrm{~min}$ and then in a refrigerator at $4^{\circ} \mathrm{C}$ for $45 \mathrm{~min}$. The samples were weighed and the thermal losses were calculated according to the formula:

cooking loss $(\%)=\frac{\begin{array}{c}\text { sample weight before cooking }(g)-\text { sample weight } \\ \text { after cooking }(g)\end{array}}{\text { sample weight before cooking }(g)} \times 100$

Shear value determination - the measurement of muscle tenderness - was performed using the TA.XT.plus texture analyser (Stable Micro Systems Ltd, Godalming, Surrey, GU71YU, UK). In order to do this, the samples (10 $\mathrm{mm}$ in diameter and $30 \mathrm{~mm}$ in height) were cut out from the cooked breast and thigh muscle $\left(85^{\circ} \mathrm{C}\right)$. The collected sample was cut with a Warner-Bratzler knife $\left(2 \mathrm{mms}^{-1}\right)$ in three places, perpendicularly to the direction of muscle fibres, while the final measurement result was provided as a mean value.

Samples of breast and thigh were collected from 6 birds of each group in order to determine the chemical composition, i.e. the contents of total dry matter, total protein (Kjeldahl method) and crude fat (Soxhlet method) and collagen using the AOAC method (2000). Cholesterol content was determined using gas chromatography (Shimadzu GC-2010 Plus). Fatty acid content was determined by gas chromatography (VARIAN $3400 \mathrm{CX}$ ) using helium as a carrier gas and column Rtx 2330 (105 m). Injector temperature was $200^{\circ} \mathrm{C}$ and detector temperature $240^{\circ} \mathrm{C}$. The samples were prepared by the method of Folch el al. (1957) using BF3/methanol methylation. Chemical analyses were performed at the Central Laboratory of the National Research Institute of Animal Production.

The study also included sensory evaluation of breast muscles and thigh muscles, according to the methodological assumptions of Baryłko-Pikielna and Matuszewska (2009). The sensory evaluation test was carried out on meat samples cooked without salt or spices to an internal temperature of $80^{\circ} \mathrm{C}$. After cooking, the muscle samples were cut into $1 \times 2 \mathrm{~cm}$ pieces, protected with aluminium foil, and marked with an identification number. Next, the samples were served for tasting to a sensory panel consisting of 10 people. The team of people included experienced and specially trained employees of the Institute. The following parameters were taken into account in the evaluation: smell, juiciness, tenderness and taste. A 5-point scale from 1 to 5 points (with an accuracy of 0.5 points) was used, with a rating of 5 being the best, and 1 being the worst. Panelists were also asked to provide comments or notes on the evaluated samples. 
The obtained results were verified statistically, and the significance of differences was specified using the Student's $t$-test (Statistica 6.0). The statistical analysis involved the determination of arithmetic mean with their standard errors (s.e.) for the traits analysed in the study.

\section{Results}

As can be seen from Table 2, health incidents and deficiencies ranged from 0.00 (Group I) to $2.50 \%$ (Group II), with 5.05 and $4.66 \mathrm{~kg}$ feed consumption per $1 \mathrm{~kg}$ increase, respectively. Table 3 shows the results of body weight and slaughter analysis of roosters and capons. At the end of fattening, i.e. in the 20th week of birds' life, the mean body weight was significantly $(\mathrm{P} \leq 0.01)$ higher (by $338 \mathrm{~g})$ in group II, i.e. in castrated birds, with significantly $(\mathrm{P} \leq 0.05)$ lower losses of whole carcass weight during storage (by 0.45 percentage point) at the same time. The capons also stood out significantly $(\mathrm{P} \leq 0.05$ and $\mathrm{P} \leq 0.01)$ with a higher slaughter capacity with and without offal (2.25 and 1.19 percentage points) and breast muscle content (1.59 percentage points). Also, the content of leg muscles was significantly $(\mathrm{P} \leq 0.01)$ higher in caponized birds (by 2.56 percentage points). In group II, a significantly ( $\mathrm{P} \leq 0.01$ ) higher proportion of internal organs (by 0.91 percentage point) was observed, especially liver and gizzard. No significant differences in the percentage of leg bones were found in the study. Roosters and capons differed significantly $(\mathrm{P} \leq 0.01)$ in terms of abdominal fat content, representing 1.64 and $3.66 \%$ of whole poultry weight, respectively. There was a large differentiation $(\mathrm{P} \leq 0.01)$ between the evaluated groups in terms of the colour of whole poultry, which were lighter $\left(\mathrm{L}^{*}=73.92\right)$ and more yellow $\left(b^{*}=14.07\right)$ and less red $\left(a^{*}=2.08\right)$ in the capons.

Table 2. Mortality and health cullings and used feed per $\mathrm{kg}$ of body weight

\begin{tabular}{|c|c|c|c|c|c|c|}
\hline \multirow{3}{*}{ Item } & \multicolumn{5}{|c|}{ Mortality and health cullings } & \multirow{3}{*}{$\begin{array}{c}\text { Feed } \\
\text { conversion } \\
\text { ratio } \\
(\mathrm{kg} / \mathrm{kg}) \\
\mathrm{x} \pm \mathrm{s} . \mathrm{e}\end{array}$} \\
\hline & \multicolumn{4}{|c|}{ number of birds } & $\%$ & \\
\hline & $\begin{array}{c}0-8 \\
\text { week }\end{array}$ & $\begin{array}{l}9-12 \\
\text { week }\end{array}$ & $\begin{array}{l}13-20 \\
\text { week }\end{array}$ & total & $\mathrm{X} \pm$ s.e & \\
\hline Cockerels & - & - & - & 0 & $0.00 \pm 0.00$ & $5.05 \pm 0.05$ \\
\hline Capons & - & 1 & - & 1 & $2.50 \pm 0.25$ & $4.66 \pm 0.06$ \\
\hline P-value & - & - & - & - & 0.359 & $\leq 0.01$ \\
\hline
\end{tabular}

The technological parameters of the chest and leg muscles are shown in Table 4. The results of the pectoral muscle acidity measurements 15 minutes after slaughter ranged from 6.31 to 6.38 , while they decreased to 5.85-5.89 after 24 hours. In the leg muscles of roosters and capons, the values of muscle acidity 15 minutes after slaughter ranged from 6.62 to 6.63 , and the decrease of $\mathrm{pH}$ after 24 hours in groups was similar and averaged 0.53 points. Significant statistical differences $(P \leq 0.05)$ were noted between roosters and capons in both pectoral and leg muscles in terms of water leakage 24 hours after slaughter $(0.15$ percentage point on average) and heat treatment losses (2.96 percentage points on average). When evaluating the colour, it was 
found that the pectoral and leg muscles in castrated birds were lighter $\left(\mathrm{L}^{*}\right)$, moreover they were characterized by a higher yellowness $\left(b^{*}\right)$ and lower redness $\left(a^{*}\right)$. Bird castration had a positive effect on pectoral and leg muscles tenderness (2.19 and 3.77 pts.) and improved water retention (2.64 and 2.39 pts.), and differences between the assessed groups of birds were statistically confirmed $(\mathrm{P} \leq 0.05$ and $\mathrm{P} \leq 0.01)$.

Table 3. Body weight and results of slaughter analysis

\begin{tabular}{|c|c|c|c|}
\hline Item & $\begin{array}{c}\text { Cockerels } \\
\mathrm{X} \pm \text { s.e. }\end{array}$ & $\begin{array}{c}\text { Capons } \\
\mathrm{x} \pm \text { s.e. }\end{array}$ & P-value \\
\hline Live body weight (g) & $3842 \pm 19.32$ & $4180 \pm 22.66$ & $\leq 0.01$ \\
\hline Carcass weight loss during chilling (\%) & $1.95 \pm 0.05$ & $1.50 \pm 0.08$ & 0.013 \\
\hline Dressing percentage with giblets (\%) & $77.65 \pm 0.42$ & $79.90 \pm 0.16$ & $\leq 0.01$ \\
\hline Dressing percentage without giblets (\%) & $73.03 \pm 0.05$ & $74.22 \pm 0.61$ & 0.012 \\
\hline \multicolumn{4}{|l|}{ Content in carcass: } \\
\hline breast muscles (\%) & $19.17 \pm 0.46$ & $20.76 \pm 0.49$ & 0.031 \\
\hline leg muscles $(\%)$ & $20.37 \pm 0.42$ & $22.93 \pm 0.39$ & $\leq 0.01$ \\
\hline Offals (\%) & $3.83 \pm 0.09$ & $4.74 \pm 0.10$ & $\leq 0.01$ \\
\hline Liver $(\%)$ & $1.48 \pm 0.08$ & $2.04 \pm 0.02$ & $\leq 0.01$ \\
\hline Gizzard (\%) & $1.85 \pm 0.06$ & $2.22 \pm 0.10$ & 0.022 \\
\hline Heart $(\%)$ & $0.50 \pm 0.01$ & $0.48 \pm 0.02$ & 0.053 \\
\hline Leg bones $(\%)$ & $7.01 \pm 0.12$ & $7.15 \pm 0.11$ & 0.220 \\
\hline Abdominal fat (\%) & $1.64 \pm 0.05$ & $3.66 \pm 0.11$ & $\leq 0.01$ \\
\hline \multicolumn{4}{|l|}{ Carcass colour: } \\
\hline $\mathrm{L}^{*}$ & $72.13 \pm 0.45$ & $73.92 \pm 0.41$ & $\leq 0.01$ \\
\hline$a^{*}$ & $3.56 \pm 0.21$ & $2.08 \pm 0.26$ & $\leq 0.01$ \\
\hline$b^{*}$ & $10.01 \pm 0.49$ & $14.07 \pm 0.34$ & $\leq 0.01$ \\
\hline
\end{tabular}

Table 4. Technological parameters of breast and leg muscles

\begin{tabular}{|c|c|c|c|c|c|c|}
\hline \multirow[t]{2}{*}{ Item } & \multicolumn{3}{|c|}{$\begin{array}{l}\text { Breast muscles } \\
\mathrm{x} \pm \text { s.e. }\end{array}$} & \multicolumn{3}{|c|}{$\begin{array}{l}\text { Leg muscles } \\
\qquad \mathrm{X} \pm \text { s.e. }\end{array}$} \\
\hline & cockerels & capons & P-value & cockerels & capons & P-value \\
\hline $\mathrm{pH}_{15}$ & $6.31 \pm 0.02$ & $6.35 \pm 0.02$ & 0.127 & $6.61 \pm 0.02$ & $6.63 \pm 0.04$ & 0.813 \\
\hline $\mathrm{pH}_{24}$ & $5.85 \pm 0.03$ & $5.89 \pm 0.03$ & 0.249 & $6.10 \pm 0.03$ & $6.09 \pm 0.03$ & 0.717 \\
\hline Drip loss after $24 \mathrm{~h}(\%)$ & $0.46 \pm 0.06$ & $0.33 \pm 0.03$ & 0.049 & $0.47 \pm 0.06$ & $0.31 \pm 0.03$ & 0.046 \\
\hline Thermal loss $(\%)$ & $23.38 \pm 0.63$ & $20.67 \pm 0.76$ & 0.042 & $31.55 \pm 0.07$ & $28.33 \pm 0.94$ & 0.047 \\
\hline \multicolumn{7}{|l|}{ Colour: } \\
\hline $\mathrm{L}^{*}$ & $56.57 \pm 0.71$ & $61.03 \pm 0.21$ & 0.013 & $47.72 \pm 1.15$ & $48.97 \pm 0.54$ & 0.457 \\
\hline$a^{*}$ & $10.96 \pm 0.46$ & $9.25 \pm 0.32$ & 0.054 & $16.03 \pm 0.57$ & $14.78 \pm 1.16$ & 0.466 \\
\hline$b^{*}$ & $7.66 \pm 0.58$ & $9.63 \pm 0.16$ & 0.033 & $6.69 \pm 0.34$ & $7.88 \pm 0.16$ & 0.038 \\
\hline Tenderness $(\mathrm{N})$ & $15.28 \pm 0.52$ & $13.09 \pm 0.48$ & $\leq 0.01$ & $20.31 \pm 0.34$ & $16.54 \pm 0.12$ & $\leq 0.01$ \\
\hline $\begin{array}{l}\text { Water holding capacity } \\
(\%)\end{array}$ & $15.53 \pm 0.60$ & $12.89 \pm 0.67$ & 0.019 & $16.97 \pm 0.34$ & $14.58 \pm 0.84$ & 0.028 \\
\hline
\end{tabular}


In the sensory evaluation (Table 5), both pectoral and leg muscles of the capons in all assessment categories scored more points than rooster meat, and the differences between the assessed groups were confirmed statistically ( $\mathrm{P} \leq 0.05$ and $\mathrm{P} \leq 0.01)$. In addition, the tasters clearly rated the leg muscles richer in fat higher $(0.53$ percentage points on average) in terms of aroma, juiciness, tenderness and taste.

Table 5. Results of sensory analysis of breast and leg muscles

\begin{tabular}{l|c|c|c|c|c|c}
\hline \multirow{2}{*}{ Item } & \multicolumn{3}{|c|}{ Breast muscles } & \multicolumn{3}{c}{ Leg muscles } \\
& \multicolumn{3}{c|}{ x \pm s.e. } & \multicolumn{3}{c}{ x.e. } \\
\cline { 2 - 7 } & cockerels & capons & P-value & cockerels & capons & P-value \\
\hline Aroma (pts.) & $4.35 \pm 0.15$ & $4.75 \pm 0.12$ & 0.025 & $4.30 \pm 0.16$ & $4.85 \pm 0.12$ & $\leq 0.01$ \\
Juiciness (pts.) & $4.30 \pm 0.12$ & $4.70 \pm 0.10$ & $\leq 0.01$ & $4.20 \pm 0.17$ & $4.75 \pm 0.10$ & $\leq 0.01$ \\
Tenderness (pts.) & $4.20 \pm 0.17$ & $4.71 \pm 0.12$ & $\leq 0.01$ & $4.35 \pm 0.19$ & $4.85 \pm 0.07$ & $\leq 0.01$ \\
Flavour (pts.) & $4.35 \pm 0.14$ & $4.79 \pm 0.10$ & $\leq 0.01$ & $4.35 \pm 0.13$ & $4.85 \pm 0.07$ & $\leq 0.01$ \\
\hline
\end{tabular}

The differences in the content of basic chemical components in rooster and capon muscles are shown in Table 6 . In both pectoral and leg muscles, castration had a significant $(\mathrm{P} \leq 0.05$ and $\mathrm{P} \leq 0.01)$ effect on increasing the content of dry matter (by 1.26 and 2.15 percentage points), total protein (by 0.68 and 0.73 percentage points) and raw fat (by 0.43 and 1.59 percentage points), respectively. Moreover, castrated birds had significantly $(\mathrm{P} \leq 0.01)$ lower collagen content $(0.55$ vs. 0.78$)$ in their pectoral muscles, which was about $60 \%$ lower than in their leg muscles. The differences between the evaluated groups in terms of ash and cholesterol were small and statistically insignificant.

Table 6. Results of effect of caponization on chemical analysis of the breast and leg muscles

\begin{tabular}{|c|c|c|c|c|c|c|}
\hline \multirow{2}{*}{ Item } & \multicolumn{3}{|c|}{$\begin{array}{l}\text { Breast muscles } \\
\quad \mathrm{x} \pm \text { s.e. }\end{array}$} & \multicolumn{3}{|c|}{$\begin{array}{c}\text { Leg muscles } \\
\mathrm{x} \pm \text { s.e. }\end{array}$} \\
\hline & cockerels & capons & P-value & cockerels & capons & P-value \\
\hline Dry matter $(\%)$ & $26.24 \pm 0.13$ & $27.50 \pm 0.12$ & $\leq 0.01$ & $25.33 \pm 0.20$ & $27.48 \pm 0.18$ & $\leq 0.01$ \\
\hline Crude ash (\%) & $1.11 \pm 0.01$ & $1.10 \pm 0.01$ & 0.594 & $1.06 \pm 0.02$ & $1.08 \pm 0.01$ & 0.526 \\
\hline Crude protein $(\%)$ & $24.17 \pm 0.17$ & $24.85 \pm 0.12$ & 0.013 & $20.08 \pm 0.14$ & $20.81 \pm 0.10$ & 0.025 \\
\hline Crude fat $(\%)$ & $1.27 \pm 0.04$ & $1.70 \pm 0.05$ & $\leq 0.01$ & $4.29 \pm 0.35$ & $5.88 \pm 0.22$ & $\leq 0.01$ \\
\hline Collagen $(\mathrm{g} / 100 \mathrm{~g})$ & $0.78 \pm 0.05$ & $0.55 \pm 0.03$ & $\leq 0.01$ & $1.62 \pm 0.11$ & $1.36 \pm 0.07$ & 0.083 \\
\hline Cholesterol (mg/100 g) & $0.58 \pm 0.01$ & $0.55 \pm 0.02$ & 0.196 & $0.88 \pm 0.01$ & $0.85 \pm 0.01$ & 0.209 \\
\hline
\end{tabular}

The content of fatty acids in the evaluated muscles is shown in Table 7. A significantly $(\mathrm{P} \leq 0.05)$ higher myristic $(\mathrm{C} 14: 0)$ and palmitic $(\mathrm{C} 16: 0)$ acid content, with lower $(\mathrm{P} \leq 0.01)$ arachidonic acid $(\mathrm{C} 20: 4 n-6)$ content was found in the pectoral muscles of the castrated birds. A significantly higher $(\mathrm{P} \leq 0.05)$ oleic acid $(\mathrm{C} 18: 1)$ content and $\alpha$-linoleic acid (C18:3n-3) content was observed in group II. In general, castrated birds showed significantly $(\mathrm{P} \leq 0.05)$ higher content of monounsaturated fatty acids (MUFA) and lower content of polyunsaturated fatty acids (PUFA), mainly from $n-6$ family. The ratio of PUFA acids of the $n-6$ and $n-3$ families in the pectoral muscles, 
important from the point of view of human dietetics, ranged from 13.50 in capons to 14.99 in roosters.

Table 7. Results of the fatty acid profile of breast and leg muscles $(\mathrm{g} / 100 \mathrm{~g})$

\begin{tabular}{l|r|r|r|r|r|r}
\hline \multirow{2}{*}{ Fatty acids } & \multicolumn{3}{c}{$\begin{array}{c}\text { Breast muscles } \\
\text { x } \pm \text { s.e. }\end{array}$} & \multicolumn{3}{c}{ Leg muscles } \\
& \multicolumn{1}{c|}{ cockerels } & \multicolumn{1}{c|}{ capons } & P-value & \multicolumn{1}{c}{ cockerels } & \multicolumn{1}{c}{ capons } & P-value \\
\hline C14:0 & $0.47 \pm 0.009$ & $0.53 \pm 0.018$ & 0.028 & $0.57 \pm 0.024$ & $0.66 \pm 0.027$ & 0.056 \\
C16:0 & $23.54 \pm 0.370$ & $25.40 \pm 0.542$ & 0.032 & $21.44 \pm 0.909$ & $25.14 \pm 0.742$ & 0.014 \\
C16:1 & $3.34 \pm 0.374$ & $4.38 \pm 0.468$ & 0.139 & $4.77 \pm 0.599$ & $6.20 \pm 0.775$ & 0.182 \\
C18:0 & $8.81 \pm 0.358$ & $7.55 \pm 0.426$ & 0.065 & $9.27 \pm 0.719$ & $6.74 \pm 0.896$ & 0.059 \\
C18:1 & $27.10 \pm 0.982$ & $32.20 \pm 1.038$ & 0.010 & $29.37 \pm 2.136$ & $35.26 \pm 1.788$ & 0.067 \\
C18:2n-6 & $18.94 \pm 1.201$ & $17.69 \pm 1.085$ & 0.447 & $23.08 \pm 1.330$ & $19.34 \pm 1.278$ & 0.078 \\
Gamma 18:3n-6 & $0.36 \pm 0.019$ & $0.32 \pm 0.021$ & 0.251 & $0.34 \pm 0.024$ & $0.23 \pm 0.013$ & $\leq 0.01$ \\
C18:3n-3 & $0.84 \pm 0.036$ & $0.99 \pm 0.039$ & 0.029 & $1.08 \pm 0.044$ & $1.26 \pm 0.067$ & 0.055 \\
C22 & $0.31 \pm 0.025$ & $0.27 \pm 0.014$ & 0.162 & $0.15 \pm 0.010$ & $0.12 \pm 0.008$ & 0.056 \\
C20:4n-6 & $14.69 \pm 0.793$ & $9.48 \pm 0.794$ & $\leq 0.01$ & $9.14 \pm 1.573$ & $4.47 \pm 0.977$ & 0.036 \\
C22:6n-3(DHA) & $1.42 \pm 0.234$ & $0.97 \pm 0.089$ & 0.090 & $0.61 \pm 0.137$ & $0.34 \pm 0.052$ & 0.097 \\
$\sum$ SFA & $33.23 \pm 0.274$ & $33.86 \pm 0.279$ & 0.157 & $31.56 \pm 0.342$ & $32.85 \pm 0.370$ & 0.034 \\
$\sum$ UFA & $66.77 \pm 0.274$ & $66.14 \pm 0.279$ & 0.157 & $68.44 \pm 0.342$ & $67.95 \pm 0.370$ & 0.071 \\
$\sum$ MUFA & $30.46 \pm 1.230$ & $36.61 \pm 1.372$ & 0.014 & $34.15 \pm 2.628$ & $41.49 \pm 2.336$ & 0.034 \\
$\sum$ PUFA & $36.32 \pm 1.205$ & $29.54 \pm 1.460$ & 0.011 & $34.29 \pm 2.833$ & $25.67 \pm 2.217$ & 0.044 \\
$\sum$ PUFA $n-6$ & $33.99 \pm 1.210$ & $27.49 \pm 1.457$ & 0.013 & $32.56 \pm 2.748$ & $24.04 \pm 2.199$ & 0.042 \\
$\sum$ PUFA $n-3$ & $2.33 \pm 0.218$ & $2.04 \pm 0.059$ & 0.196 & $1.73 \pm 0.120$ & $1.63 \pm 0.046$ & 0.443 \\
PUFA $n-6 / n$-3 & $14.99 \pm 1.539$ & $13.50 \pm 0.800$ & 0.393 & $18.89 \pm 1.230$ & $14.76 \pm 1.189$ & 0.042 \\
\hline & & & & & &
\end{tabular}

The structure of fatty acids in the leg muscles was similar to that in the pectoral muscles. A significantly $(\mathrm{P} \leq 0.05)$ higher saturated fatty acid (SFA) content, especially palmitic acid (C16:0) was also shown here in the group of the castrated birds. Significantly higher $(\mathrm{P} \leq 0.05)$ content of oleic acid $(\mathrm{C} 18: 1)$ and lower content of $\gamma$-linolenic (Gamma18:3n-6) and arachidonic acid (C20:4n-6) was observed in group II. The capon group showed significantly higher $(\mathrm{P} \leq 0.05)$ content of monounsaturated fatty acids (MUFA) and lower content of polyunsaturated PUFA, especially from the $n-6$ family. The PUFA $n-6 / n-3$ acid ratio ranged from 14.76 in capons to 18.89 in roosters $(\mathrm{P} \leq 0.05)$.

\section{Discussion}

The quality of meat obtained from native breeds of chickens differs significantly from that of broiler chickens (Połtowicz and Doktor, 2012; Sokołowicz et al., 2016). These changes mainly relate to colour, fat cover, muscle fibre thickness, tenderness, 
chemical and sensory characteristics of the meat and depend on the genotype of the birds, their rearing methods, feeding and slaughter age. As Yin et al. (2013) indicated, later maturing birds are predisposed to breeding in extensive conditions, with a good rate of weight gain, therefore a way to improve the growth and muscularity of birds is to cross different breeds of hens, which was also used in our own research. The obtained hybrids (the capons) were distinguished by a significantly higher body weight compared to purebred hens, i.e. Rhode Island Red, by more than $35 \%$ (Calik et al., 2017), and from hens of the Yellowleg Partridge breed ( $\dot{Z}-33)$, by more than $45 \%$ (Calik, 2015). At the same time, a good rate of weight gain produced for the experiment with hybrids allowed reducing the fattening period by 4 weeks compared to the fattening of capons obtained from pure families. Similar results were obtained by Krawczyk et al. $(2018,2019)$ in a study carried out on hybrid poulardes resulting from the crossing of native breeds of hens with meat roosters. The authors noted a good rate of weight gain of hybrids, which reduced the poularde fattening period by as much as 5 weeks compared to pure hen breeds (Obrzut et al., 2018).

As Chen et al. (2006) and Shao et al. (2009) indicated, there are changes in the appearance and behaviour of males observed after castration, as a result of testosterone deficiency, in a relatively short period of time, which was also observed in our study. This concerned secondary sexual traits, i.e. comb and wattle, which became pale yellow and were subject to regression within a few weeks. The birds after the treatment became calmer, less active and aggressive, they generally did not run and did not show any desire for mating. The observed falls and shortages of health were low and did not exceed $2.5 \%$, and concerned the first days after castration. As Rikimaru et al. (2009) indicate, caponization losses vary from 5 to $20 \%$ and depend primarily on the age at which the birds are castrated. Rahman et al. (2004) and Chen et al. (2007) also stress that this is a key factor, and that performing castration in the first weeks of life is more beneficial, due to the higher survival rate of the birds, better weight gain and meat quality.

Nutrition plays a very important role in capon production. It is generally recommended that they should be divided into 2 to 3 periods, and $70 \%$ of their diet should be cereals, supplemented with roughage. For centuries, the final feeding period of the capons has been indicated, back then they were given noodles prepared from barley or oat flour, milk, honey and herbs, and giving milk or whey was also practiced. In order to meet the expectations of consumers, who are paying more and more attention to the way the birds are fed, in our experiment we have developed starter and grower diets, as well as finisher feed in granulated form, which was additionally enriched with $4 \%$ added milk, giving it to both groups of birds during the last 4 weeks of fattening. Rearing and fattening of capons were more efficient using the same compound feed for birds. The capons gained weight over $4 \mathrm{~kg}$, with an average feed consumption of $4.66 \mathrm{~kg} / \mathrm{kg}$ of growth. Lower feed consumption in sterilized birds was also shown by Shao et al. (2009), Rikimaru et al. (2009) and Calik et al. (2017). At the same time, the authors emphasize that both the origin and timing of the treatment has a fundamental impact on the efficiency of use expressed in terms of feed intake and feed use per kg growth. In the study carried out on the poulardes by Krawczyk et al. (2019) it has been demonstrated that the addition of $4 \%$ powdered milk or 
whey in compound feed during the last fattening period during the final growth phase has had a beneficial effect on lower feed consumption per kg of growth, higher bird body weight and improved sensory properties of meat.

The research has shown a beneficial effect of hybrid rooster caponization on their final body weight. The positive influence of the sterilization procedure on the body weight has been indicated in the studies by Duran et al. (2004), Rikimaru et al. (2009), Diaz et al. (2010), Kwiecień et al. (2015), Franco et al. (2016), Calik et al. (2017), Kwiecień et al. (2018). The authors indicate that the lower motor activity of castrated birds, affects the better use of feed, which is associated with higher weight gain and the deposition of particularly valuable intramuscular fat. In a study by Miguel et al. (2008) conducted on Castellana Negra chickens, and a study by Murawska et al. (2019) conducted on cockerels, there was no weight advantage of castrated roosters over uncastrated ones reported on Leghorn roosters, which may be related to the genetic origin of the birds, their feeding, age at castration, susceptibility to stress or slaughter date.

In our study, castration of roosters also had a positive effect on higher slaughter yield of whole poultry with and without offals, and differences between the evaluated groups were confirmed statistically. In comparison with previous studies (Calik, 2015), it was shown that the slaughter yield with and without offals of the obtained hybrid capons, was over $8 \%$ higher compared to the pure Yellowleg Partridge ( $\dot{Z}-33)$ breeding line. In addition, the capons were also distinguished by a significantly higher content of pectoral and leg muscles, which is consistent with the studies by Duran (2004) and Mahmud et al. (2013). Improvement of slaughter yield and capon body muscle was also noted in studies carried out on native breeds of hens, i.e. Yellowleg Partridge (Calik, 2015), Rhode Island Red (Calik et al., 2017) and Sussex (Calik et al., 2018). Studies conducted by Kwiecień et al. (2015) demonstrated greater share of pectoral muscles in capon whole poultry, and lower share of legs than in roosters, while a study by Adamski et al. (2016 b) showed lower pectoral and leg muscle share. The assessed groups of birds differed in terms of the internal organ share, and the greatest effect was exerted by the liver and gizzard share, which was significantly higher in sterilized birds. This corresponds to the results obtained by Rahman et al. (2004), Chen et al. (2006, 2007), Zawacka et al. (2017) and Murawska et al. (2019). The authors indicate that the liver is the main site of fatty acids synthesis in birds, and the increase in its mass may be caused by increased lipogenesis processes. In authors' own research, as in the research by Tor et al. (2005), there were no significant differences in the proportion of bones, but only a tendency towards higher values in castrated roosters. Adamski et al. (2016 a), by comparing the physical characteristics of Sussex S-11 cockerel and capon bones found that with age in the capons, bone strength increases significantly, which may indicate a positive effect of castration on this characteristic. Then again Tomaszewska et al. (2016) demonstrated that the caponizing procedure performed on Greenleg Partridge roosters did not affect bone mass and length, but decreased the mineral density of the femur. The groups of birds we evaluated differed significantly in terms of whole poultry fattening. According to Sinanoglou et al. (2011) and Adamski et al. (2016 b), capons are characterized not only by a higher content of fat in the saddle, but also subcutaneous and intramuscu- 
lar fat. Moreover, as indicated by Rikimaru et al. (2009) rooster castration reduces testosterone concentration and increases lipogenesis and lipid accumulation in the body. The higher fat content of the capons in comparison to uncastrated roosters could be a source of skin colour differences. According to studies by the Lin and Hsu (2002), and our previous study (Calik et al., 2015, 2017), the evaluated capon whole poultry stood out with a lighter $\left(\mathrm{L}^{*}\right)$ and more yellow $\left(\mathrm{b}^{*}\right)$ colour, and lower redness (a*). In the study by Sirri et al. (2009), the capons showed a lower content of hem pigments, and their concentration in muscles largely affects the appearance of poultry meat.

The caponizing procedure did not affect the $\mathrm{pH}$ of the pectoral and leg muscles, which is consistent with the results obtained by Diaz et al. (2010), Volk et al. (2011), Amorim et al. (2016) and Adamski et al. (2016 b). The $\mathrm{pH}_{15}$ values in the groups were higher in comparison with $\mathrm{pH}_{24}$, which proves correct glycolytic changes in muscles and proper maturation of muscle tissue. In addition, the pectoral and leg muscles of the capons were characterized by a more favourable water absorption rate, with less permeation and thermal losses, which is consistent with the results carried out on purebred capons (Calik et al., 2017, 2018). As with the whole poultry, the pectoral muscles of the capons were lighter and more yellow, while the rooster muscles were more red. Similar differences occurred in the case of the colour development of leg muscles, which is consistent with results obtained by Sirri et al. (2009) and Franco et al. (2016). As indicated by Symeon et al. (2012) and Amorim et al. (2016), muscle colour depends mainly on breed, sex, age and physical activity of birds, which is mainly determined by myoglobin and intramuscular fat content. Moreover, these factors have a direct effect on the acidity of meat, which in turn is closely related to water absorption (Augustyńska-Prejsnar and Sokołowicz, 2014). The authors emphasize that meat with high water absorption loses less meat juice during heat treatment, and therefore, apart from higher yield, retains higher juiciness. This has a direct impact on the assessment of its palatability, which is one of the most important characteristics of meat for the consumer. The higher tenderness of capon meat compared to rooster meat is indicated by the results by Rikimaru et al. (2009), Sirri et al. (2009), Lin and Hsu (2013), Calik et al. (2017, 2018). Moreover, as Lin and Hsu (2002), as well as Gesek et al. (2017, 2019) showed, smaller diameter of muscle fibres also favours greater meat tenderness, as observed in capon muscles. As indicated by Wojtysiak et al. (2019), tenderness of meat depends on the content, composition and intramuscular structure of connective tissue, but also on the degree of post-slaughter degradation of myofibrillar and cytoskeletal muscle fibres. The authors demonstrated a significant effect of the caponizing procedure on increasing the rate of dystrophin degradation in pectoral muscle fibres, as compared to roosters. Moreover, they stress that changes in the rate of protein degradation after death not only affect the structure of muscle fibres, but also translate into physicochemical parameters of meat.

As Volk et al. (2011) and Lin and Hsu (2013) indicate, the fat contained in the muscles limits the drying out of muscle tissue during heat treatment and promotes the sensation of juiciness. In addition, a higher accumulation of fat in the muscles contributes to the improvement of sensory characteristics, and that meat is character- 
ized by greater palatability, juiciness and tenderness, which is consistent with the obtained results. In the sensory evaluation, both the pectoral and the leg muscles of the capons received higher scores for all traits. At the same time, tasters clearly rated leg muscles richer in fat higher, in terms of smell, juiciness, tenderness and taste. A better sensory quality of castrated birds is indicated in studies by Adamski et al. (2016 b), Amorim et al. (2016), Franco et al. (2016) and Gesek et al. (2017). Moreover, Puchała et al. (2014) found that meat from birds of native or locally adapted breeds has a more intense smell and taste. In addition, Obrzut et al. (2018) and Krawczyk et al. (2019) indicate that meat from indigenous breeds or hybrids is tastier and more tender than that from hens. As indicated by Augustyńska-Prejsnar and Sokołowicz (2014), the concentration of the palatability precursors increases with the age of the birds, reaching its maximum after puberty. In addition, muscles with greater activity during the period of survival exhibit a stronger aroma than muscles with less activity, hence the greater intensity of taste and aroma characterize leg muscles than pectoral muscles, which was also noted in our own research.

The study showed significant differences in the nutritional value of capon and rooster muscles. The analysis of the chemical composition of the muscles indicates that castration did not affect the ash content of the pectoral and leg muscles, which is consistent with studies by Miguel et al. (2008) and Amorim et al. (2016). Both the pectoral and leg muscles of castrated birds were distinguished by a significantly higher content of dry matter and fat, which corresponds to the results obtained by Lin et al. (2013), Kwiecień et al. (2015), Calik et al. (2017) and Obrzut et al. (2018). A significantly higher protein content was recorded in the pectoral and leg muscles of the capons. Its level was over $24.5 \%$ and was about $4.5 \%$ higher than that of young broiler chickens (da Silva et al., 2017) and similar to the Hubbard $\times$ Goldel Comet hybrids (Sirri et al., 2009), native breeds (Calik, 2015) and the Spanish Mos breed (Franco et al., 2016). A significantly higher protein content in the muscles of castrated birds is indicated by the results obtained by Amorim et al. (2016), Kwiecień et al. (2015) and Calik et al. (2018). As demonstrated by Janicki and Buzała (2013), collagen constitutes $20-30 \%$ of proteins in birds' body and is the basic component of intramuscular connective tissue. The high content of this imperfect protein in the connective tissue of the muscles has a significant effect on the tenderness of the meat, lowering its quality. In addition, the cross-linked collagen in highly active muscles increases with the animal's age, making the meat hard. Lower collagen content was found in meat of late-maturing and castrated animals (Sokołowicz et al., 2016). In the analysed samples of pectoral and leg muscles of capons, the collagen content was significantly lower by $29 \%$ and $16 \%$, respectively, compared to uncastrated roosters, with significant differences confirmed only for pectoral muscles. Moreover, the pectoral muscles contained about $60 \%$ less collagen than the femoral muscles, which was also noted by Amorim et al. (2016), with comparable protein content in muscles. There were no significant differences between the assessed groups of birds in terms of cholesterol content, which is consistent with the studies conducted by Lin and Hsu (2013), as well as Kwiecien et al. (2015). On the other hand, a higher cholesterol content in both the pectoral and leg muscles of the capons is showed by the results of studies by Sirri et al. 
(2009), as well as only in the pectoral muscles as demonstrated by Franco et al. (2016).

According to Miguel et al. (2008), Sirri et al. (2009) and Diaz et al. (2012), the profile of fatty acids in rooster and capon muscles is affected by bird genotype, nutrition and age. Our studies have shown a significant effect of castration on the total content of monounsaturated fatty acids (MUFA) in pectoral muscles. There was also a significant increase in oleic acid (C18:1) and $\alpha$-linoleic acid (C18:3n-3), with a decrease in arachidonic acid (C20:4n-6). A similar structure of acid composition was noted in leg muscles, but with a higher content of saturated fatty acids (SFA), especially palmitic acid. The results obtained are consistent with those of Rikimaru et al. (2009) who carried out research on Hinai-jidori chickens. In addition, Kwiecien et al. (2018), in their studies performed on native breeds of hens: the Greenleg Partridge $(\mathrm{Zk})$ and Polbar $(\mathrm{Pb})$, showed higher content of MUFA, lower content of arachidonic acid (C20:4n-6) and higher content of SFA, especially palmitic acid (C16:0), in capons of the Polbar $(\mathrm{Pb})$ breed. Our own research indicates a lower ratio of PUFA $n-6 / n-3$ acids in castrated birds, beneficial from the point of view of human dietetics. The lower ratio of $n-6 / n-3$ acids in castrated birds has also been demonstrated by Sirri et al. (2009), Franco et al. (2016), Calik et al. (2017) and Kwiecień et al. (2018).

\section{Conclusion}

Based on the results of production efficiency, carcass characteristics and the chemical composition of the muscles, it can be concluded that the hybrids obtained from the crossbreeding of the Yellowleg Partridge ( $\dot{Z}-33)$ and Ross 308 meat roosters are good material for capon production. They can complement poultry meat production with a niche product for consumers looking for products of exceptional quality.

\section{References}

A d a m s ki M., K uźn i a c k a J., B a na s z a k M., We g n e r M. (2016 a). The analysis of meat traits of Sussex cockerels and capons (S-11) at different ages. Poultry Sci., 95: 125-132.

A d a m s ki M., K uźn i a c k a J., B a n a s z a k M. (2016 b). The effects of strain and caponisation on carcass and meat traits of cockerels aged twenty weeks. Ann. Anim. Sci., 16: 1227-1239.

Amorim A., Rodrigues S., Pereira E., Valentim R., A. Teixeira A. (2016). Effect of caponisation on physicochemical and sensory characteristics of chickens. Animal, 10: 978-986.

AOAC (2000). Official methods of analysis. 17th ed. Gaithersburg: AOAC International.

A ugustyńska-Prejs n a r A., S o k ołow i c z Z. (2014). Factors affecting the sensory quality of broiler chicken meat (in Polish). Wiad. Zoot., 2: 108-116.

B a ryłko-Pikielna N., Matuszewska I. (2009). Sensory testing of food (in Polish). Wyd. Nauk. PTTZ, 367 pp.

Calik J. (2014). Capon production - breeding stock, rooster castration, rearing methods, and meat quality. Ann. Anim. Sci., 14: 769-777.

C a 1 i k J. (2015). Effect of caponizing Yellowleg Partridge (Ż-33) cockerels on body weight and meat quality. Acta Sci. Pol., Zoot., 14, 1: 51-60.

Calik J., Połtowicz K., Świątkiewicz S., Krawczyk J., Nowak J. (2015). Effect of caponization on meat quality of Greenleg Partridge cockerels. Ann. Anim. Sci., 15: 541-553.

Calik J., Krawczyk J., Ś wi ąt ki ew ic z S., G ąs ior R., Wojtyczka K., P ołtowicz K., 
O brzut J., P u c hała M. (2017). Comparison of the physicochemical and sensory characteristics of Rhode Island Red (R-11) capons and cockerels. Ann. Anim. Sci., 17: 903-917.

C a li k J., Kraw c z y k J., O b r z u t J. (2018). Physicochemical and sensory characteristics of meat in Sussex (S-66) cocks and capons (in Polish). Zywn-Nauk. Technol. Ja., 115: 48-58.

Chen K.L., H s i eh T.Y., Chi o u P.W.S. (2006). Caponization effects on growth performance and lipid metabolism in Taiwan country chicken cockerels. Asian-Australas. J. Anim. Sci., 19: 438-443.

Che n K.L., Chen T.T., L in K.J., C h i o u P.W.S. (2007). The effect of caponization age on muscle characteristics in male chicken. Asian-Australas. J. Anim. Sci., 20: 1684-1688.

CIE (2007). Draft Standard 014-4.3/E: Colorimetry - Part. 4: CIE 1976 L*a*b* colour space. Vienna, Austria: p. 8.

Commission Regulation (EC) No 543/2008 of 16 June 2008 laying down detailed rules for the application of Council Regulation (EC) No $1234 / 2007$ as regards the marketing standards for poultry meat.

da Silva D.C.F., de Arruda A.M.V., Gonçalves A.A. (2017). Quality characteristics of broiler chicken meat from free-range and industrial poultry system for the consumers. J. Food Sci. Technol., 54: 1818-1826.

Diaz O., Rodríguez L., Torres A., Cobos A. (2010). Chemical composition and physicochemical properties of meat from capons as affected by breed and age. Span. J. Agric. Res., 8: 91-99.

Di a z O., R odríguez L., Torres A., Cobos A. (2012). Fatty acid composition of the meat from Mos breed and commercial strain slaughtered at different ages. Grasas Aceites, 63: 296-302.

D u r a n M.A. (2004). The effect of caponzation on production indices and carcass and meat characteristic in free-range Extremena Azul chickens. Span. J. Agric. Res., 2: 211-216.

F ol ch J., L e e s M., S l o a n e-S t a n l e y G.H. (1957). A simple method for the isolation and purification of total lipids from animal tissues. J. Biol. Chem., 226: 497-509

Fran co D., P a te ir o M., R o i s D., V á z que z J.A., L o r e n zo J.M. (2016). Effects of caponization on growth performance, carcass and meat quality of Mos breed capons reared in free-range production system. Ann. Anim. Sci., 15: 909-929.

Ge se k M., Z aw a cka M., Muraw ska D. (2017). Effects of caponization and age on the histology, lipid localization, and fiber diameter in muscles from Greenleg Partridge cockerels. Poultry Sci., 96: 1759-1766.

Ge sek M., Murawska D., Otrocka-Domagała I., Paździor-Czapula K., Michals k a K. (2019). Effects of caponization and age on the histology of the internal organs of Leghorn cockerels. Brit. Poultry Sci., 60: 176-185.

Gr a u R., H a m m R. (1953). Eine einfache Methode zur Bestimmung der Wasserbindung im Muskel. Naturwiss, 40: 29-30.

Janicki B., Buzała M. (2013). Effect of collagen on technological quality of meat (in Polish). Zywn-Nauk. Technol. Ja., 87: 19-29.

Kraw c z y k J. C a lik J. (2018). Quality assessment of eggs laid by hens included in programmes for the conservation of animal genetic resources (in Polish). Zywn-Nauk. Technol. Ja., 116: 140-150.

Krawczyk J., Obrzut J., Calik J. (2018). Effects of genotype and sterilization of chickens on growth rate, slaughter yield, whole poultry colour and physicochemical properties of poularde meat obtained from a hybrid breed of conservative chickens and meat roosters. Europ. Poultry Sci., 82: $1-14$.

Kraw c zy k J., Obrzut J., Ś w i ąt k i e w i c z S., C a li k J. (2019). The effect of slaughter age and the diet in the final growth phase of poulards on productivity and meat quality. Ann. Anim. Sci., 19: 499-516.

Kw i e c ień M., Kas perek K., Grela E., Jeżew ska - Witk ow ska G. (2015). Effect of caponisation on the production performance, slaughter yield and fatty acid profile of muscles of greenleg Partridge cocks. J. Food Sci. Technol., 52: 7227-7235.

Kwi ecień M., Kasperek K., Tomaszewska E., Muszyński S., Jeżewska-Wit kowska G., Winiarska - Mi eczan A., Grela E., Ka mińska E. (2018). Effect of breed and caponisation on the growth performance, carcass composition, and fatty acid profile in the muscles of Greenleg Partridge and Polbar breeds. Braz. J. Poultry Sci., 20: 583-594.

L in C.Y., H s u J.C. (2002). Effect of surgical caponization on growth performance, fiber diametr and some physical properties of muscles in Taiwan country chicken cockerels. Asian-Australas. J. Anim. Sci., 15: 401-405. 
L in C.Y., H s u J.C. (2013). Comparison of skin and muscle color, muscle composition and sensory panel score of capon, slip and intact birds in Taiwan country chicken cockerels. J. Taiwan Lives. Res., 46: 187-194.

Mahmud M.A., Shaba P., Gana J., Yis a H,Y., Ndagimba R. (2013). Effects of surgical caponisation on growth, carcass and some hematological parameters in cockerel chickens. Sokoto J. Vet. Sci., 11: 57-62.

Miguel J.A., Ciria J., A s enj B., Calvo J.L. (2008). Effect of caponisation on growth and on carcass and meat characteristics in Castellana Negra native Spanish chickens. Animal, 2: 305-311.

Murawska D. Gees ek M., Witkowska D. (2019). Suitability of layer-type male chicks for capon production. Poultry Sci., 98: 3345-3351.

Obrzut J. Krawczyk J., Calik J., Świątkiewicz Ś., Pietras P., Utnik-Banaś K. (2018). Meat quality of poulards obtained from three conserved breeds of hens. Ann. Anim. Sci., 18: 268-281.

P o ł t o w i c z K., D o k t o r J. (2012). Effect of slaughter age on performance and meat quality of slowgrowing broiler chickens. Ann. Anim. Sci., 12: 621-631.

Puchała M., Kraw c z y k J., C a li k J. (2014). Influence of origin of laying hens on the quality of their carcasses and meat after the first laying period. Ann. Anim. Sci., 14: 685-696.

R ah m a n M.M., I s 1 a m M.A., A li M.Y., K hon d a k e r M.E.A., Ho s s a in M.M. (2004). Effect of caponization on body weight, hematological traits and blood cholesterol concentration of Nara chicken. Int. J. Poult. Sci., 3: 284-286.

Rikimaru K., Shiji O., Komastu M., Ishizuka J. (2009). Effects of caponization on meat quality of Hinai-jidori chicken. Int. J. Poult. Sci., 46: 345-350.

R i k i maru K., Tak a ha s hi H., N i chlos M.A. (2011). An efficient method of early caponization in slow-growing meat-type chickens. Poultry Sci., 90: 1852-1857.

Sh a o Y., Wu C., Li J., Z h a o C. (2009). The effect of different caponization age on growth performance and blood parameters in male Tibetan chicken. Asian-Australas. J. Anim. Sci., 4: 228-236.

Sinanoglou V.J., Mant is F., Miniadis-Meimaroglou S., Symeon G.K., Bize1 is I.A. (2011). Effects of caponisation on lipid and fatty acid composition of intramuscular and abdominal fat of medium-growth broilers. Brit. Poultry Sci., 52: 310-317.

Sirri F., Bianchi M., Petracci M., Meluzzi A. (2009). Influence of partial and complete caponization on chicken meat quality. Poultry Sci., 88: 1466-1473.

S o k o łow i c z Z., Kr a w c z y k J., Ś w i ą t k i e w i c z S. (2016). Quality of poultry meat from native chicken breeds - a review. Ann. Anim. Sci., 16: 347-368.

Symeon G.K., Mant is F., Bizelis I., Kominakis A., Rogdak is E. (2010). Effects of caponization on growth performance, carcass composition, and meat quality of medium growth broilers. Poultry Sci., 89: 1481-1489.

Symeon G.K., Mant is F., Bizelis I., Kominakis A., Rogdakis E. (2012). Effects of caponization on growth performance, carcass composition and meat quality of males of a layer line. Animal, 6: 2023-2030.

Tor M., Estany J., Villalba D., Molina E., Cubilò M.D. (2002). Comparison of carcass composition by parts and tissues between cocks and capons. Anim. Res., 51: 421-443.

Tor M., Estany J., Francesch D.A., Cubilò M.D. (2005). Comparison of fatty acid profiles of edible meat, adipose tissues and muscles between cocks and capons. Anim. Res., 54: 413-424.

Tomaszewska E., Kw i ecien M., Muszynski S., Dobrowolski P., Kasperek K., B li charski T. (2016). Long-bone properties and development are affected by caponisation and breed in Polish fowls. Brit. Poultry Sci., 19: 159-170.

Volk M., Malenš e k J., Prevolnik M., Š krle p M., Š e gula B. Č a ndek-P ot o kar M., B a ve c M. (2011). Differences in carcass and meat quality between organically reared cocks and capons. Agric. Conspec. Sci., 76: 153-155.

Wojtysiak D., Calik J., Krawczyk J., Wojciechowska-Puchałka J., Obrzut J., $\mathrm{Nahaj} \nmid$ o K. (2019). Postmortem degradation of desmin and dystrophin in breast muscles from capons and cockerels. Ann. Anim. Sci., 19: 835-846.

World Watch List for Domestic Animal Diversity, 2000 - 3rd edition FAO/UNEP, Roma.

Y in H.D., Gil bert E.R., Chen S.Y., Wang Y., Zhang Z.C., Z h a o X.L., Zh ang Y., Zhu Q. (2013). Effect of hybridization on carcass traits and meat quality of Erlang mountainous chickens. Asian-Australas. J. Anim. Sci., 26: 1504-1510. 
Z aw a cka M., Muraws ka D., Ges e k M. (2017). The effect of age and castration on the growth rate, blood lipid profile, liver histology and feed conversion in Green-legged Partridge cockerels and capons. Animal, 11: 1017-1026.

Zawacka M., Gesek M., Michalik D., Murawska D. (2018). Changes in the content of edible and non-edible components and distribution of tissue components in cockerels and capons. Span. J. Agric. Res., 16:e0602.

Z i ołecki J., D or u chowski W. (1989). Evaluation methods of slaughter value (in Polish). Wyd. COBRD, Poznań, Polska, pp. 1-22.

Received: 14 IV 2020

Accepted: 3 VII 2020 